\title{
Comparing metadiscourse markers employed in English and Persian online headlines
}

Yazdani, Akram

English Department, Faculty of Humanities, Najafabad Branch, Islamic Azad University, Najafabad, Isfahan, Iran (divinedear662@yahoo.com)

Salehi, Hadi $\bowtie$

English Department, Faculty of Humanities, Najafabad Branch, Islamic Azad University, Najafabad, Isfahan, Iran(Hadisalehi1358@yahoo.com)

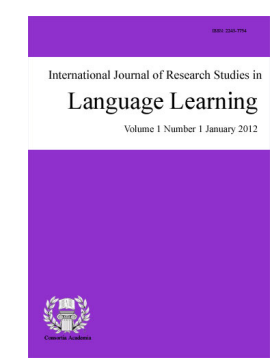

ISSN: $2243-7754$ Online ISSN: 2243-7762

OPEN ACCESS

Received: 20 June 2016

Revised: 10 July 2016

Accepted: 10 August 2015

Available Online: 14 September 2016

DOI: $10.5861 /$ ijrsll.2016.1554

\section{Abstract}

This study aimed to investigate the differences in the use of metadiscourse markers between Persian and English online headlines about the first two months of the year 2015. To this end, the corpora in the present study comprise a total of 100 Persian and English online headlines (each 50 headlines) were chosen randomly from English and Persian newscasts such as VOA, CNN, Bistosi (20:30), and Bashgahkhabarnegaran. The specific research area of interest was whether online Persian and English headlines made a similar field-specific use of metadiscourse markers. The corpora were recorded and divided in two groups of Persian online headlines and English online headlines. The corpora also consisted of different fields, politics, economic, sport, entertainment, cultural, social, and world news. According to Hyland's (2005) model, interactive and interactional metadiscourse markers were identified in online headlines. The analysis revealed that according to descriptive statistics Persian fields made more use of the metadiscourse markers than English fields. The findings of this research would help to keep journalism students aware of this aspect of metadiscourse.

Keywords: metadiscourse; English headlines; Persian headlines; field-specific 


\title{
Comparing metadiscourse markers employed in English and Persian online headlines
}

\section{Introduction}

Metadiscourse is generally used to announce what writers will do to list the parts or steps in the presentation, to express logical connection, to show the degree of writers' certainty, or to indicate their intentions. Metadiscourse, as Hyland (2000) defined, can be defined as the linguistic elements used to organize either a text toward its content or the writer's opinion towards the readers, and are characterized as a set of cohesive items which assist the reader organizes, links, and interprets the sentences in a preferred way by the writer.

Definitions of metadiscourse as a rhetorical strategy which rely on a clear-cut distinction between discourse (content) and metadiscourse (non-content) is shaky. Especially when analyzing naturally-occurring-speech, it cannot be assumed that all forms of communication about communication can be adequately separated from communication itself. Instead of defining metadiscourse as a level or plane of language, or a distinct unit separate from primary discourse, metadiscourse can be conceptualized as a rhetorical strategy used by speakers and authors to talk about their own talk (Crismore, 1989). The writers' awareness of disciplines and languages specific uses of metadiscourse elements is necessary to adopt their texts into a language and discipline's norms, values and ideologies and also to express their meanings so that they seem credible and convincing. In this process, writing is viewed as a social engagement and reveals how writers of different disciplines and languages position themselves within their discourse to signal their attitudes towards propositional contents and the audiences.

Metadiscourse can be viewed from two perspectives, textual and interpersonal. It can be limited to text organizing features (textual feature) which help readers process the text and interpret it consistently with their epistemological understanding and genre expectations. By the organizing role of metadiscourse, we assume the authors use of textual metadiscourse, in order to form a cohesive and coherent text and thus increase its readability. However, the way the writer organizes his or her text depends on the writer's estimation of how a well-organized and comprehensible text look like and is strongly influenced by the writing culture the writer belongs to (Blagojevic, 2004). The second point of view, which seems more comprehensive, adds the interactive elements or interpersonal features to help express the writers' attitudes and sureness and increase the force and persuasive texts of different discourse lends itself to the use of interpersonal metadiscourse (Williams, 1989). Those resources that:

\begin{abstract}
Allow the writer to manage the information flow to explicitly establish his or her preferred interpretations. They are concerned with ways of organizing discourse to anticipate readers' knowledge and reflect the writer's assessment of what needs to be made explicit to constrain and guide what can be recovered from the text (Hyland, 2004).
\end{abstract}

The online newspaper which serves as an influential medium in keeping people informed about world events and, thereby, in extending their knowledge in deepening their understanding in these days' communities has not received much attention in previous studies; especially, headlines which show the most prominent and relevant information of the news discourse. "The headlines form the summary of the news story, which strategically servers as the expression of its macrostructure" (van Dijk, 1988). Since readers often read and recall only headlines, they construct not only preferred meaning of the news texts for the readers but also the most prominent ideological view of the text (van Dijk, 1988).Therefore, this study aimed to illuminate how English and Persian journalists persuade their readers in terms of using metadiscourse markers in online headlines.

This study generally aimed to scrutinize a comparative analysis of metadiscourse markers in online headlines written by English and Iranian journalists. The specific objective of this study is to scrutinize whether online English and Persian headlines make a similar field-specific use of metadiscourse elements or not. In 
addition, this study as a contrastive research took a step in the direction of analysis of metadiscourse markers in online headlines of the newspapers. It is hoped that this study gave significant insights into the teaching of English as a foreign language in general and the teaching of writing in English in particular. The study is beneficial for EFL students and their teachers in analyzing, understanding and correcting their intercultural linguistic problems in writing. The findings of the study are also beneficial for translation area (both for teachers and students in translation courses and professional translators). It is also practical to train journalism students about using metadiscourse markers appropriately in order to achieve more success in reporting the world events.

\section{Literature Review}

There is no consensus on defining the boundaries of metadiscourse and the term persists in being fuzzy. Swales (1990) maintained that while the concept is easy to accept in principle, it is more difficult to establish its boundaries. However, generally, according to Hyland (2005, p. 18), "rhetoricians, applied linguists and composition theorists agree on using metadiscourse in a wider sense, to refer to various linguistic tokens employed to guide or direct a reader through a text so (that) both the text and the writer's stance is understood".

Metadiscourse is also defined as self-reflective linguistic expressions referring to the communication triangle; the evolving text (Crismore, 1989; Hyland, 2004). This definition is based on a view of writing as a social engagement and, in academic contexts, reveals the ways writers project themselves into their discourse to signal their attitudes and commitments. Another definition is given by Hyland (2005), who strongly opposed the primary/secondary distinctions made by some scholars. He maintained that metadiscourse "is the cover term for the self-reflective expressions used to negotiate interactional meaning in a text, assisting the writer or speaker to express a viewpoint and engage with readers as members of a particular community". Hyland and Tse (2004) suggested three criteria to identify metadiscourse:

Metadiscourse is distinct from propositional aspects of discourse;

$>\quad$ the term metadiscourse refers to those aspects of the text that embody writer-reader interactions;

$>$ Metadiscourse distinguishes relations which are external to the text from those that are internal (p. 159).

According to Hyland (2005, p. 39), the first criterion does not mean that metadiscourse only supports propositional content; rather "it is the means by which propositional content is made coherent, intelligible, and persuasive to a particular audience". The second criterion rejects the duality of interpersonal and textual functions found in much of the metadiscourse literature and suggests that all of metadiscourse is interpersonal in that it takes account of the reader's knowledge, textual experiences and processing needs and that it provides writers with an armory of rhetorical appeals to achieve this (Hyland, 2005). Textual function, however, can serve both interpersonal and propositional purposes. The distinction between the two leads to the third criterion. That is, when the textual function refers to external relations, it is not part of metadiscourse. Kopple (1985) divided language into two parts:

$>\quad$ Propositional content of a text, sometimes called the facts or statements carrying the truth and values to be proved true or false.

$>\quad$ The metadiscourse or human influence upon that propositional content as it is packaged and processed for dissemination.

The model proposed by Hyland (2005) assumed the two main categories of interactive and interactional for metadiscourse. Following the distinction made by Thompson and Thetela (1995) to acknowledge the organizational and evaluative features of interaction (Table 1). The model has drawn upon several earlier models. 
Yazdani, A., \& Salehi, H.

\section{Table 1}

Interpersonal Model of Metadiscourse (Hyland, 2005)

\begin{tabular}{|c|c|c|}
\hline Category & Function & Examples \\
\hline Interactive & $\begin{array}{l}\text { Help to guide the reader through } \\
\text { the text }\end{array}$ & Resources \\
\hline Transitions & $\begin{array}{l}\text { Express relation between main } \\
\text { clauses }\end{array}$ & In addition; but; thus; and \\
\hline Frame markers & $\begin{array}{l}\text { Refers to discourse acts, } \\
\text { sequences, or stages }\end{array}$ & $\begin{array}{l}\text { Finally, to conclude, my purpose is } \\
\text { Noted above, see figure, in section } 2\end{array}$ \\
\hline Endophoric markers & $\begin{array}{l}\text { Refer to information in other } \\
\text { parts of the text }\end{array}$ & According to $\mathrm{X}, \mathrm{Z}$ states \\
\hline Evidential & $\begin{array}{l}\text { Refer to information from other } \\
\text { text }\end{array}$ & $\begin{array}{l}\text { Namely, e.g., such as, in other words } \\
\text { resources }\end{array}$ \\
\hline Code glosses & Elaborate propositional meanings & \\
\hline Interactional & $\begin{array}{l}\text { Involve the reader in the text } \\
\text { Emphasize certainty or close } \\
\text { dialogue }\end{array}$ & $\begin{array}{l}\text { About, in fact, definitely, it is clear that } \\
\text { Unfortunately, I agree, surprisingly } \\
\text { I, me, my, our }\end{array}$ \\
\hline Boosters & $\begin{array}{l}\text { Express writers attitude to } \\
\text { proposition }\end{array}$ & $\begin{array}{l}\text { Might, perhaps, possible } \\
\text { Consider, note, you can see that }\end{array}$ \\
\hline Attitude markers & $\begin{array}{l}\text { Explicit reference to author } \\
\text { Withhold commitment and open }\end{array}$ & \\
\hline Self-mentions & dialogue & \\
\hline Hedges & $\begin{array}{l}\text { Explicitly build relationship with } \\
\text { readers }\end{array}$ & \\
\hline Engagement markers & & \\
\hline
\end{tabular}

\section{Methodology}

The present study is a descriptive research which generally applies quantitative data collection method to conduct an in-depth analysis of the usage of metadiscourse markers between Persian and English online headlines. The corpus of this study was a set of English and Persian data composed of 100 online headlines (50 written in English and 50 in Persian). The selected online English headlines were from VOA and CNN. Online Persian headlines were selected from Bistosi (20:30) and BashgahKhabarnegaran to increase homogeneity of our corpus. As in the case of other comparative and contrastive studies, ensuring the comparability of the two corpora of the study is primary important. Therefore, in order to meet this comparability requirement, online headlines in both groups were selected from a diverse and different topics including social, political, economic, cultural, entertainment, sport, and world news.

A model of Hyland (2005) was employed as an instrument to analyze interactive and interactional metadiscourse markers of 50 English online headlines and 50 Persian online headlines to disclose the differences between these headlines in using interactive and interactional metadiscourse markers. The data collection for our research was consisted of retrieving a large portion of headlines from the electronic version of elite and influential English and Persian headlines in the United States and Iran through the internet. Due to the research aim, it was determined that there had to be several newscasts serving as the database for the study. In more precise terms, the headlines of different newscasts were quite diverse in their styles or textual strategies (Fowler, 1991; Shams, 2005); therefore, in order to reduce stylistic influence of journalists and newscasts in the analysis, an extended scope of data -4 newscasts (2 in English and 2 in Persian) were selected. English newscasts include of VOA and CNN. Persian newscasts are Bistosi (20:30) and Bashgahkhabarnegaran.

In order to ensure that diachronic changes do not affect the selected online headlines, only headlines published in the period between the first two months of the year 2015 (January and February) were included in the sample. In this study, regarding the first question, 100 online headlines, 50 in English and 50 in Persian were culled from the selected online headlines for a close contrastive analysis. After retrieving a large portion of headlines from newscasts ( 2 in English and 2 in Persian) and selecting the headlines which compose the corpus 
of the study. Online headlines were read word by word carefully so as to find out the interactive and interactional metadiscourse markers frequency based on K Hyland's (2005) model. The markers were counted manually. All the data were analyzed twice by the researcher to prevent any fault in counting the frequency of the markers. The data were also evaluated by a master student of English Teaching and a university lecturer who were expert in the field and had similar knowledge regarding interactive and interactional metadiscourse markers based on $\mathrm{K}$ Hyland's (2005) model. Frequencies of these metadiscourse markers were compared between English and Persian online headlines.

\section{Results}

The second research question of the study was "Do online English and Persian headlines make a field-specific use of metadiscourse elements?" To find an answer to this research question, chi-square was also used to compare the frequencies of field-specific metadiscourse elements in online English and Persian headlines. Table2 depicts the frequencies of English and Persian field-specific headlines as well as the number of words and metadiscourse elements therein.

Table 2

Frequencies of Different Field-Specific Headlines, Words, and Metadiscourse Elements in English and Persian

\begin{tabular}{|c|c|c|c|c|}
\hline Field & Language & No. of headlines & No. of words & No. of meta-discourse elements \\
\hline \multirow{2}{*}{ Politics } & English & 20 & 150 & 13 \\
\hline & Persian & 11 & 169 & 16 \\
\hline \multirow{2}{*}{ Sports } & English & 1 & 7 & 0 \\
\hline & Persian & 9 & 107 & 14 \\
\hline \multirow{2}{*}{ Social news } & English & - & - & - \\
\hline & Persian & 10 & 144 & 14 \\
\hline \multirow{2}{*}{ World news } & English & 16 & 115 & 15 \\
\hline & Persian & - & - & - \\
\hline \multirow{2}{*}{ Entertainment } & English & 11 & 90 & 13 \\
\hline & Persian & 6 & 65 & 6 \\
\hline \multirow{2}{*}{ Economy } & English & 2 & 24 & 0 \\
\hline & Persian & 5 & 60 & 6 \\
\hline \multirow{2}{*}{ Cultural } & English & - & - & - \\
\hline & Persian & 5 & 60 & 6 \\
\hline
\end{tabular}

Concerning the descriptive statistic of research question two, in the collected data, some specific fields were not found at all in a language: no world news were among the Persian news headlines and no cultural or social news were found in the English news collected. Table2 could be inferred that the difference between the frequencies of metadiscourse elements in English and Persian field-specific online headlines reached statistical significance. As could be seen in Figure 1, the frequencies of Persian metadiscourse elements were higher than English ones in the case of Politics (16 to 13), Economy (6 to 0), and particularly Sports news (14 to 0). It was only entertainment news in which the frequency of English metadiscourse elements surpassed the Persian ones. Table 3 shows the results of Chi-square analysis performed for comparing the frequencies of metadiscourse elements in English and Persian field-specific news.

\section{Table 3}

Chi-Square differences between English and Persian Metadiscourse elements in Field-Specific Online Headlines

\begin{tabular}{llll}
\hline & Value & $d f$ & Asymp. Sig. (2-sided) \\
\hline Pearson Chi-Square & 20.24 & 3 & .000 \\
Likelihood Ratio & 26.87 & 3 & .000 \\
Linear-by-Linear Association & .034 & 1 & .854 \\
N of Valid Cases & 68 & & \\
\hline
\end{tabular}

Based on the magnitude of the $p$ value in Table 3 (that is, .000), it could be inferred that the difference 
Yazdani, A., \& Salehi, H.

between the frequencies of metadiscourse elements in English and Persian field-specific online headlines reached statistical significance. The differences are vividly shown in the bar graph below (Figure 1).

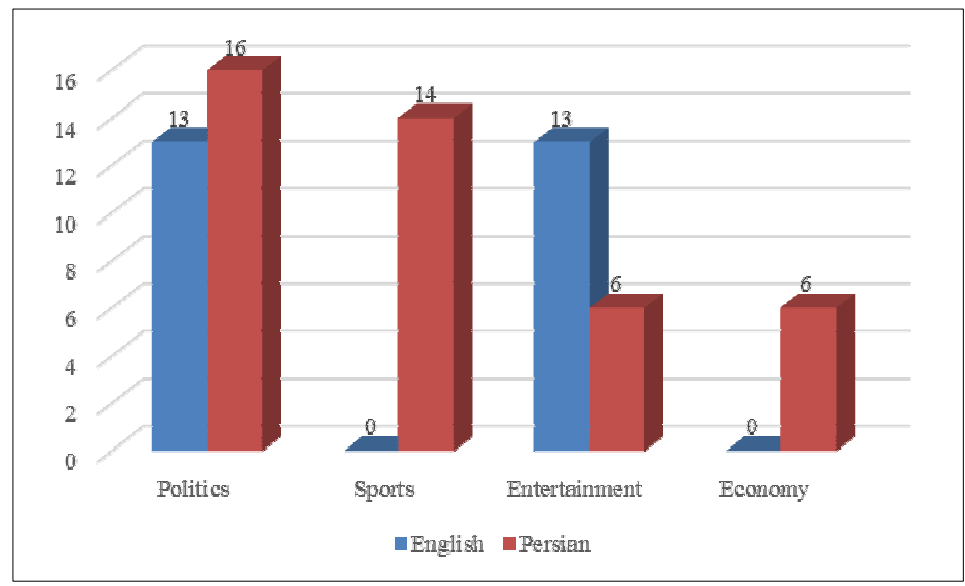

Figure 1. Frequencies of Field-Specific Metadiscourse Markers in Persian and English Headlines

As could be seen in Figure 1, the frequencies of Persian metadiscourse elements were higher than English one in the case of Politics (16 to 13), Economy (6 to 0 ), and particularly Sports news (14 to 0 ). It was only entertainment news in which the frequency of English metadiscourse elements surpassed the Persian ones.

\section{Discussion and Conclusion}

Fuertes-Olivera et al. (2001) examined the use of metadiscourse in slogans and headlines which used typically by copywriters. Their results demonstrated that textual and interpersonal metadiscourse help copywriters to convey a persuasive message through an informative task. "The headlines form the summary of the news story, which strategically servers as the expression of its macrostructure" (van Dijk, 1988). Since readers often read and recall only headlines, they construct not only preferred meaning of the news texts for the readers but also the most prominent ideological view of the text (van Dijk, 1988).

Concerning the descriptive statistic of research question two, in the collected data, some specific fields were not found at all in a language: no world news were among the Persian news headlines and no cultural or social news were found in the English news collected. It could be inferred that the difference between the frequencies of metadiscourse elements in English and Persian field-specific online headlines reached statistical significance. As could be seen in Figure 1, the frequencies of Persian metadiscourse elements were higher than English ones in the case of Politics (16 to 13), Economy (6 to 0), and particularly Sports news (14 to 0). It was only entertainment news in which the frequency of English metadiscourse elements surpassed the Persian ones.

Based on descriptive analysis of field-specific of the study, the difference between the frequencies of metadiscourse elements in English and Persian field-specific online headlines reached statistical significance. The frequencies of Persian metadiscourse elements were higher than English ones in the case of Politics (16 to 13), Economy (6 to 0 ), and particularly Sports news (14 to 0). It was only entertainment news in which the frequency of English metadiscourse elements surpassed the Persian ones.

It is hoped that the result of this study gave significant insights into the teaching of English as a foreign language in general and the teaching of writing in English in particular. It is necessary to make learners aware of these markers and their functions in the text, for example, language texts from prominent websites can be applied to emphasize their appropriate use. Students should pay attention to the appropriate use of interactive and interactional metadiscourse markers in online headlines. The result of the study is beneficial for EFL students and their teachers in analyzing, understanding, and correcting their intercultural linguistic problems in writing. Teachers can encourage students to apply these metadiscourse markers appropriately. The findings of the study 
are also beneficial for translation area (both for teachers and students in translation courses and professional translators). It is also practical to train journalism students about using metadiscourse markers appropriately in order to achieve more success in reporting the world events.

\section{References}

Blagojevic, S. (2004). Metadiscourse in academic prose: A contrastive study of academic articles written in English by English and Norwegian native speakers. Kalbu Studijos, (5), 60-67.

Crismore, A. (1989). Talking with readers: Metadiscourse as rhetorical act. New York: Lang.

Fowler, R. (1991). Language in the news: Discourse and ideology in the press. London: Taylor and Francis.

Fuertes-Olivera, P. A., Velasco-Sacristán, M., Arribas-Baño, A., \& Samaniego-Fernández, E. (2001). Persuasion and advertising English: Metadiscourse in slogans and headlines. Journal of Pragmatics, 33(8), 1291-1307. http://dx.doi.org/10.1016/S0378-2166(01)80026-6

Hyland, K. (2000). Disciplinary discourses: Social interactions in academic writing. Stationery Office.

Hyland, K. (2004). Disciplinary interactions: Metadiscourse in L2 postgraduate writing. Journal of Second Language Writing, 13(2), 133-151. http://dx.doi.org/10.1016/j.jslw.2004.02.001

Hyland, K. (2005). Metadiscourse: Exploring interaction in writing. Bloomsbury Academic.

Hyland, K., \& Tse, P. (2004). Metadiscourse in academic writing: A reappraisal. Applied Linguistics, 25(2), 156-177. http://dx.doi.org/10.1093/applin/25.2.156

Kopple, V. (1985). William J. Some explanatory discourse on metadiscourse. College Composition and Communication, 36, 82-93. http://dx.doi.org/10.2307/357609

Shams, M. R. (2005). Reading English newspapers. Jungle Publication Tehran.

Swales, J. (1990). Genre analysis: English in academic and research settings. Cambridge University Press.

Thompson, G. (2001). Interaction in academic writing: Learning to argue with the reader. Applied Linguistics, 22(1), 58-78. http://dx.doi.org/10.1093/applin/22.1.58

van Dijk, T. A. (1988). The analysis of news as discourse. In T. A. van Dijk (Ed.), News analysis. Case studies in international and national news in the press (pp. 1-30). New Jersey: Hillsdale.

Williams, J. M. (1989). Style: Ten lessons in clarity and grace. Boston, MA: Scott, Foresman and Co. 
Yazdani, A., \& Salehi, H. 